\title{
Mapping of functions of the process based on functional resonance analysis: action research in a pig producer unit
}

Alexandre Stainke ${ }^{1}$, University of Taquari Valley, Lajeado, Rio Grande do Sul, Brazil.

Cláudio Roberto do Rosário ${ }^{2}$, University of Taquari Valley, Lajeado, Rio Grande do Sul, Brazil.

Douglas Henrique Flach ${ }^{3}$, University of Taquari Valley, Lajeado, Rio Grande do Sul, Brazil.

\section{RESUMO}

Objetivo - Este estudo visa mapear as funções do processo da Unidade de Criação de Leitões.

Referencial teórico - O trabalho aponta uma revisão literária sobre engenharia de resiliência, visão holística, modelagem de processos e sistema sociotécnico.

Desenho / metodologia / abordagem - Baseado no Método de Análise de Ressonância Funcional (FRAM) e no uso da pesquisa-ação como metodologia de pesquisa para orientar as etapas do estudo.

Resultados - A aplicação prática do estudo proporcionou a projeção de margens para manobras operacionais, permitiu a visibilidade das operações em âmbito macro, apoiou a decisão dos gestores e instigou a repensar a forma como cada função era desempenhada. As ações propostas por meio do estudo vão ao encontro da gestão de processos, buscando identificar e reduzir gargalos de produção, sob a ótica da engenharia de produção.

Originalidade / valor - O mapeamento do processo com aspectos relacionados a cada função proporcionou o reflexo de ações que cooperariam com o gestor da unidade na definição da melhor decisão a ser tomada com base na estrutura e no grau de importância do sistema utilizado. O FRAM permite aumentar o grau e tipo de variabilidade, permitindo visualizar a função com o maior número de variáveis.

Palavras-chave - Tomada de decisão, processos de gestão, mapeamento de funções, gargalos produtivos.

\section{ABSTRACT}

Purpose - This study aims to map the process functions of the Piglet Breeding Unit.

Theoretical framework - The work points out a literary review of resilience engineering, holistic view, process modeling and socio-technical system.

Design/methodology/approach - Based on the Functional Resonance Analysis Method (FRAM) and the use of action research as a research methodology to guide the study steps.

Findings - The practical application of the study provided the margin projection of for operational maneuvers, allowed the visibility of operations in a macro scope, supported the decision made by managers and instigated to rethink the way each function was performed. The actions proposed through the study meet the process management, seeking to identify and reduce production bottlenecks, from the perspective of production engineering.

Originality/value - The mapping of the process with aspects related to each function provided the reflection of actions that would cooperate to the unit manager in defining the best decision to make based on the structure and the degree of importance in the system used. FRAM allows the increasing of the degree and type of variability, allowing you to view the function with the largest number of variables.

Keywords - Decision making, management processes, function mapping, productive bottlenecks.

1. asteinke@universo.univates.br, https://orcid.org/0000-0002-3549-4114; 2. University of Taquari Valley, Rua Avelino Talini, 171 - Bairro Universitário, Lajeado/RS, CEP 95914-014, Brazil, claudio.rosario@univates.br, https://orcid.org/0000-0002-75483380; 3. douglas.flach@universo.univates.br, https://orcid.org/0000-0002-3427-278X

STAINKE, A.; ROSÁRIO, C.R.; FLACH, D.H. Mapping of functions of the process based on functional resonance analysis: action research in a pig producer unit. GEPROS. Gestão da Produção, Operações e Sistemas, v. 15, n. 4, p. 78 - 114, 2020.

DOI: http://dx.doi.org/10.15675/gepros.v15i4.2667 


\section{INTRODUCTION}

Planning and controlling the operations of a production process represent one of the biggest challenges for organizations. The efficient management of available resources, given the countless new variables presented daily, depends on the correct decision making. Gonçalves (2000) states that managing processes and obtaining maximum results derive from actions such as mapping the organization's activities and rules and relationships that exist with the external environment.

The complexity of the operations and the variability in which they occur due to the large number of possibilities and interference exist in accordance with the studies by Wachs (2016). The author states that, in view of an efficient management system for decision making in production processes, there is a need for integration between improvements in operating procedures and training among operators in a complex socio-technical system. Fogaça (2015) states that the variability in sociotechnical systems occurs due to the presence of variations in different offices, thus generating non-linear results.

In complex technical partner systems, the dynamism, the variety, the doubts and the influences that occur between the elements that compose it, shapes the system, being necessary the ability of resilience to keep it functioning (DEKKER et al., 2013). This ability to adapt to the flow of functions in situations of conflict or transformation in order to keep operations in an acceptable condition and how to carry out work in unexpected conditions, defines the concept of resilience engineering (HOLLNAGEL, 2011) and addresses the analysis of practical work carried out on a daily basis as a key point in modeling management in operations.

Studies like Rassmussen's (1997) suggest that complex systems are subject to different pressure vectors (economic, security, audit, quality) and often hear conflicting meanings. Test pressure can lead to the production system in an area of instability with a security aspect, just as decisions under economic pressure can bring instability to quality aspects. As productive systems are dynamic, and susceptible to internal and external variables, the stability of your process is at risk. Dekker (2003) adds that a way of absorbing the impacts suffered by the variation of pressures and conflicting goals, there is no phenomenon of adaptation to work, is not qualified as impaired people, based on their empirical experience, in recent years, due to their empirical experience, making it possible to meet the pressure for results, shortening 
procedures, but giving up the security protocol. Based on this need for quick adaptation to meet pressure in the system and adequacy of imminent variables in the processes, Hollnagel et al. (2008) suggests that measures that provide an application of resilience engineering be taken.

This perspective introduces the concept of Leveson (2006) for resilience, being the system's ability to prevent or adapt to circumstances that generate instabilities, in order to maintain control over a system property. Dekker (2011) defines the resilient system as being the one that can adjust its functioning before during and after the occurrence of disturbances or variations. The concept of resilience applied in organizations has been called resilience engineering (WACHS, 2016). Vargas and Guimarães (2006) reinforce the importance that resilience engineering should not only explain the events that cause a system to fail, but learn from the near failures that the impacts of variability cause on the system. Thus, it is a matter that seeks, ultimately, to predict and prepare actions for the possibilities of failures in the future.

To conceptually model the system, using a method that encompasses a systemic look at the analyzed functions, we need to consider the variables in the different operations, seeking the simultaneous development and structuring of the problem in the real period in which it occurs (LIPSHITZ et al., 2001).

For Gonçalves (2000), managing processes to obtain maximum results, mapping activities, rules and existing relationships with the external environment, is what determines the development of the organizational structure. The organization necessarily needs to adapt to changes such as globalization so that it can make the decisions demanded by its process managers acceptable. For Fogaça (2015), mapping the functions of the process based on Functional Resonance analysis cooperates in the understanding and holistic responses of the process, enabling the identification of bottlenecks and the need to speed up the decision making. In this sense, the present study is part of the analysis of the functions used in the management of the productive process, considering the different variables, such as the analysis of the controls, the resources, the conditions and the progress, the inputs and the outputs in each process function. their interactions, as well as the balance between each function.

Initially, from reading works such as Hollnagel (2012), Rasmussen (1997), Dekker (2003; 2011), where resilience engineering is avoided as an alternative to mitigate the 
variation of sociotechnical systems and promote greater linearity in aspects of execution, safety and quality, it was defined or theme addressed and delimitation of the object of study.

Under the aspect of managing a business, the practice of visual management, within the workplace can be carried out by projecting margins of maneuver, with redundant equipment, described in processes, training of operators and coverage of highly complex environments (WACHS, 2016). In this sense, Portela (2016) proposes the establishment of a link chain between proactive indicators, risk analysis and process resilience, in order to ensure compliance with Resilience Engineering practices, under the management aspect of the process under study.

Thus, in the decision-making process, the first action is to structure the problem, assess the variables of the information system that support decision making, and assess the difficulties to clearly define what must be decided and determined. Thus, the production of personalized and timely information facilitates the long-term strategic management view (WZOREK; REZENDE; MENDES, 2008).

Thus, were mapped the areas directly linked to the management of production processes that influence the management decision making of a Piglet Production Unit (UPL), a company located in the Taquari Valley - RS, through the Functional Resonance Analysis Method. - FRAM. It was possible to diagnose the role of each of the functions of the productive system and its implications in the decision-making process. From this point, the problem was structured, the variables that support decision making and the identification of actions to be taken in the production unit.

\section{THEORETICAL REFERENTIAL}

This section discusses the assumptions surrounding process management from the perspective of complex systems.

\subsection{Holistic view and process modeling}

In the managerial view, strategic objectives are based on processes. These are modeled through the evaluation of the production process, performance measurement, management reports, systems and information technologies (COELHO; COSTA; PILATTI, 2006). Given the great complexity of operations, there was a need for an enlarged view of the functions. In 
this sense, the holistic view is based on the management of the processes studied in reengineering, which preaches the enlarged view of the processes (OULD, 2005).

The holistic view brings several improvements in the systems, by tuning in an integrative approach to sustainability of the organization, which added to the Lean philosophy, brings promising results (DÜES et al., 2013; GALEAZZO et al., 2014). In this sense, there was a growing interest in the emerging challenge of 'process orientation' or the integration of actors from end to end (ELKINGTON, 2013; NEWMAN; DALE, 2005). Thus, the end-to-end view of the process is a product of the product of stakeholder interactions and collective decision-making (ADOLPHE; ROUSVAL, 2007; DEAKIN et al., 2002; HAAPIO, 2012; YANG et al., 2015).

Making better processes requires planning, business leadership, integration for improvements, analysis and management, the result of process management that is directly linked to the systemic view, resulting in efficiency and added value in product or service delivery (FOGAÇA, 2015). In this sense, processes are defined by the order of the activities of a work in relation to time and space, the visible identification of the beginning and the end, the inputs and outputs, the activities that are performed, the objective of producing something with coherence and which aims at customer value (HAMMER; CHAMPY, 1999). Processoriented structures aim to organize resources and flows throughout the operation, abdicating role-structured models (GONÇALVES, 2000).

The fast pace of technological changes brings numerous variables and dangers and increases the complexity and the coupling of processes. Thus, processes must be considered as socio-technical systems, and not just technical systems, considering that operations need to be supported by interactions between technologies, human and organizational factors (LEVESON, 2004; PERROW, 1999; RASMUSSEN, 1997). The complexity increases due to the interactions between the different variables, which can follow simple cause and effect relationships in a small group and come together in non-linear and circular relationships, leading to failures (CAMERON et al., 2017). Any disturbances or interruptions affect the processes due to the coupling of the components.

Today, these processes are the heart of organizations, thanks to movements that have enhanced process improvements, workflow management systems, reengineering, and process management. Thus, organizations should develop processes that seek to meet market 
demands, adding value to the good or service, in view of the conception of customers with quality and competitive prices.

The behavior in this system is usually unpredictable, and it is interesting to focus on how to analyze each step, separating them into parts, and investigating each one separately (FOGAÇA, 2015). Given the complexity of these systems, where organizations are operating, and the increasing speed with which change occurs, business continuity is related to their ability to direct efforts to adapt to the market and be resilient.

In this sense, for process evaluation, or FRAM, it can be integrated with probabilistic models and to quantify changes according to the performance variables of the functions (PATRIARCA; DI GRAVIO; COSTANTINO， 2017; PATRIARCA; DI GRAVIO; COSTANTINO, et al. 2017). In addition, FRAM shows the benefits used to understand the advanced systems of large scale and multi-level systems and offers the possible possibilities to break the complex system on a large scale and computationally simulated as interactions at different levels, allowing a holistic assessment of processes of greater complexity.

\subsection{Resilience engineering}

The concept of resilience is based on the ability to sustain or quickly recover from unforeseen circumstances without causing downtime during or after significant organizational problems. In this sense, a new concept is integrated between the organizational levels, aligning the procedures with the objectives of the organization, making it more stable, safe and qualified (PORTELA, 2016). Fogaça (2015) points to resilience as an interference factor in the formation of the model, characterizing the peculiarities of the individual in how to get around conflicts, thus increasing the number of combinations that influence responses.

Among the fundamental principles, resilience engineering states that efficiency and functionality are characteristics of adaptability of sociotechnical systems, whose equivalence of success or failure is associated with the constant adjustment between rules, resources, scenarios and their combinations (COLLIGAN; HOLLNAGEL HOUNSGAARD, 2014). In this sense, the sustainability of organizations goes beyond their capacity for innovation, flexibility and resilience, demanding agility and efficiency in their decision making. Decision making within an organization is of great importance in strategic planning and is addressed below through Functional Resonance Analysis (FRAM). 
In addition, for Praetorius, et al. (2015) resilience engineering skills (response, monitoring, anticipation and learning) are employed to develop systems resilience and ways to strengthen and support the necessary functioning during many different operational conditions. This view is shared by Hollnagel, Woods and Leveson. (2006), who describe that resilience engineering, where systems are analyzed with the aid of four pillars, monitoring, response, anticipation and learning, which characterize the resources that the system must have to remain in operation, before, during and after the planned and unforeseen events.

\subsection{Functional Resonance Analysis (FRAM)}

One of the biggest challenges in organizations is to make the right decisions in the management of operational processes, analyzing the large flow of information and possibilities arising from technological advancement, automation and knowledge, generating complex conflicts in the management of organizations. The need for quick and assertive decision responses is understood, preserving system integrity and balancing conflicts in operations management (WACHS, 2016).

In this line, this work leads to the study of systemic mapping of operations in the management process of organizations, analyzing the balance of input and output of information in each process, the variability presented in conflict management, becoming a model for making decisions of operations. The proposal of using a model to perform the analysis of functions within the management of the organization met what Hollnagel (2012) calls Functional Resonance, whose functions generate different combinations and results, requiring further study to assist in making of decisions arising from the proceedings.

Functional Resonance Analysis Method - FRAM has been developed by Hollnagel $(2009,2012)$ and aims to describe the results of a system by analyzing the influences of variables in multiple functions. The variables that imply manager performance in complex systems emphasize the relationship between human factors and resilience to the systemic understanding of errors and successes (DEKKER, 2003).

The FRAM model is dedicated to its conceptual modeling of variables in various functions, with a qualitative focus on the information it receives from the system, determining which inputs, outputs, indispensable resources, available times, how to perform controls and, if necessary, some precondition to perform the activities in the functions of the model studied, allowing a comprehensive and systematic caveat of the functions evaluated (STEEN; AVEN, 
2011). The links between functions can be defined as the number of couplings (NOCs) that occur between the aspects of each function, the outputs being the "downstream NOCs", and the inputs, resources, time, precondition and control the "NOCs" upstream".

A diagnosis based on the FRAM model focuses on the elaboration of 4 repeated steps as needed (HOLLNAGEL, 2012): identify and describe the essential functions of the system; identify variability; aggregate the variables; and make recommendations (actions). In the initial stage, the functions that are important in the system to be studied are identified, as well as their operating characteristics, not understanding how they were created, but how they are performed on a daily basis. In this step the characteristics of the essential functions in the method conception are recommended, relating them to six aspects: Input, outputs, preconditions, resources, time and control.

Figure 1 - Representation of the steps of the FRAM through an hexagon

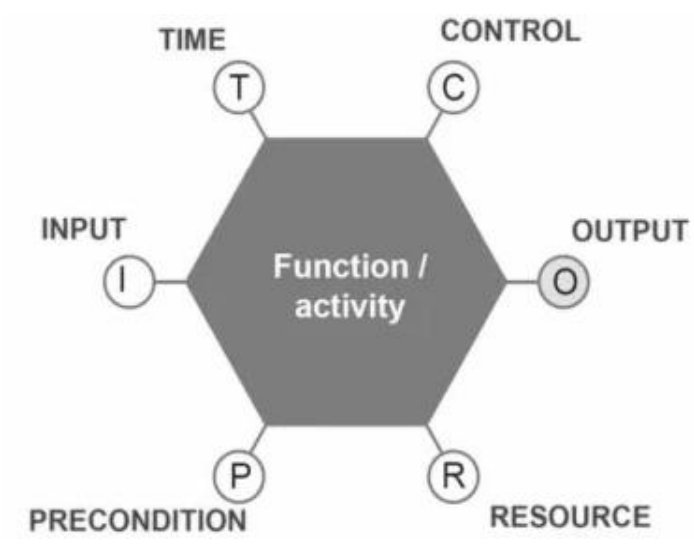

Source: Hollnagel (2009).

For Hollnagel, Pruchnicki, Woltjer, et al. (2008), in the function characterization stage, a separate analysis of each task should be performed, its procedures and the knowledge included in them. Thus, as interviews to map functions, they should follow the structure of Table 1. 
Table 1 - Steps of the characterizacion of the functions of the FRAM

\begin{tabular}{l|l} 
Steps & Description \\
\hline Input $(\mathrm{I})$ & $\begin{array}{l}\text { Defines which elements are needed to begin the processo of transformation and action in } \\
\text { each function; }\end{array}$ \\
\hline Output $(\mathrm{O})$ & It's the result of the function, change occurs or entity transformation; \\
\hline Precondition $(\mathrm{P})$ & What conditions must be met before the function begins to play its role; \\
\hline Resources $(\mathrm{R})$ & What is needed to produce outputs in the function; \\
\hline Time (T) & $\begin{array}{l}\text { Identify the restrictions that affects the beggining, the middle and the final limit in each } \\
\text { function; }\end{array}$ \\
\hline Control $(\mathrm{C})$ & Points out how to monitor the aspects related to the function production.
\end{tabular}

Source: Hollnagel, Pruchnicki, Woltjer, et al. (2008).

Once the functions and their characteristics are defined, they are connected to each other, according to the reality sought about their operation, linking the functions by different aspects, as appropriate, and may be linked in different ways. These links tend to reproduce the relationship between functions, making their operation visible and easy to understand, and identifying crucial points in the study of variability (WACHS, 2016).

For Almeida (2008), the commitment of efficiency and quality in the development of activities is the result of negotiation between the parties, whose monitoring and adjustments are necessary so that there are no differences between planned and executed. In the next step, the ability to undergo variation or change is observed in each function, analyzing from the expected to how much it can potentiate this change, influencing the operation of the system as a whole, or interfering with output factors in a certain function (WOLTJER, 2009).

The first objective in this step is to provide clarification in terms of adjustments of behavior variability by describing in each function the actual variables that have occurred. The second is to identify which aspects are linked to other functions, characterizing the input (E) in the next function, rewriting the links between them, until complete characterization of the process scenario (HOLLNAGEL; PRUCHNICKI; WOLTJER, et al., 2008). In the practical implementation of the model, it is possible to identify bottlenecks in the management of functions, in which through the representation in hexagon, the resonance model allows the identification of variability between inputs and outputs of each function.

In the FRAM execution stage, the proposal is to manage possible uncontrolled variability conditions in the performance of functions (functional resonance), to prevent 
barriers in its development, to facilitate processes in reducing possible errors, to eliminate risks, and to mitigate the implications that the other measures failed to resolve. For Wachs (2016), performing FRAM implementation work on a daily basis results in a series of results that contribute to the visualization of the process functions as a whole.

The application of FRAM for complex systems represents a valuable solution to obtain a better understanding of the functional interactions of the system. To capture dynamics and non-linear interdependencies, FRAM describes complex systems by their functions and not by physical structures (HERRERA, WOLTJER. 2010). Its successful applications in risk assessment and accident analysis in different contexts occur in several areas, such as in aviation (NOUVEL; TRAVADEL; HOLLNAGEL, 2007; HOLLNAGEL; PRUCHNICKI; WOLTJER; ETCHER, 2008; STEEN; AVEN, 2011), railroad (STEEN; AVEN, 2011; BELMONTE; SCHÖN; HEURLEY; CAPEL, 2011), nuclear power plant (LUNDBLAD; SPEZIALI, 2008), medical assistance (SUJAN; FELICI, 2012), process industry (SHIRALI; MOHAMMADFAM, 2013) and maritime (PRAETORIUS; HOLLNAGEL; DAHLMAN, 2015).

\subsubsection{Analysis and choice of variables for the FRAM}

The behavior of the complex system is a result of the aggregate performance of individual functions, and therefore, it cannot be explained by a simple logic of causal effect. The functions involved in processes (technological, organizational or human) have performance variability, which means that they can adjust their behavior to reach a specific object of the system. Interactions of its performance can generate unintended variations, causing unexpected events in the system. The steps to identify the functional resonance through the FRAM were described by Hollnagel (HOLLNAGEL, 2017), who talks about the variables and their behaviors.

For Hollnagel (2017), in stage of identification of the performance variability, the performance variability of each function is identified and described through the time and precision of the function output. The variability in terms of time and precision is described through similar linguistic levels for qualitative understanding

In aggregation of performance variability, the variations in the output performance of the upstream functions can serve as any aspect, with the exception of the results of the downstream functions, and can reduce, increase or not yet interfere in the performance 
variability of the result of the downstream functions. The limitation of qualitative performance variables in the previous step makes understanding the synchronic effects complex when a downstream function is affected by other upstream functions and requires quantifying the effects of damping or amplifying its upstream functions (HOLLNAGEL, 2017).

Consequence and analysis stage: After adding the performance variability, the dangers and their corresponding uncontrollable performance variability can be identified. Measures to eliminate or mitigate hazards can be carried out (HOLLNAGEL, 2017).

\subsection{Action Plan 5W2H}

After verifying the pertinent demands to the evaluated processes, a work is done focused on the solvability of the issues. Understood as an Action Plan, the 5W2H tool structures the implementation of a solution in the desired process in an organized way (BEHR, 2008). This method follows sequence and ordered patterns, guiding the actions that should be performed and implemented (BRUM, 2013). The english meaning of the letters of the name names their use in actions:

Table 2 - Action Plan 5W2H

\begin{tabular}{c|c} 
5W2H & Description \\
\hline What & What is going to be done (steps); \\
\hline Why & Why it is going to be done (justification); \\
\hline Where & Where it is going to be done (place); \\
\hline When & When it is going to be done (time); \\
\hline Who & Who is going to do (responsability); \\
\hline How & How is it going to be done (method); \\
\hline How much & How much it is going to cost (cost).
\end{tabular}

Source: BRUM, 2013.

The 5W2H-based Action Plan can be applied to correct a diagnosis by solving the problems analyzing and orchestrating the implementation of multiple actions simultaneously. After identifying the actions to be implemented through the implementation of FRAM, the Piglet Producing Unit made use of the tool to enable the actions proposed by the study.

\section{METHODOLOGICAL PROCEDURES}

The present work approaches the inductive and dialectical methods in the research. For Gil (2008), the inductive method consists in the systematic observation of reality, 
formulating a general basis on particular cases, resulting in the explanation of the phenomenon as a whole. The dialectic, on the other hand, consists in the method of arguing and dialoguing with something that cannot be demonstrated, restricting it to rational opinions.

The method of approach used in the study is qualitative, that does not take into account the numerical representativeness in the research, but rather the understanding of the facts, which should be done and analyzed by different aspects of approach. The research methodology regarding objectives is classified as Exploratory and Explanatory Research. According to Gil (2008), exploratory research aims to familiarize the problem through bibliographic surveys, interviews with people who have had experiences with the problem, and the analysis of examples that result in the understanding of the problem. Explanatory research records facts, analyzes them, interprets them and identifies their causes (LAKATOS; MARCONI, 2001).

In the application of FRAM in a practical context, there are many variables to be observed, in order to allow the tool to be successful in interpreting the functions added to it. Once the functions and their characteristics are defined, they are connected to each other, according to the reality sought about their functioning. These links tend to reproduce the relationship between the functions, making it visible and easy to understand to identify crucial points in the study of variability (WACHS, 2016).

According to Almeida (2008), the commitment to efficiency and quality in the development of activities is the result of negotiation between the parties, whose monitoring and adjustments are necessary so that there are no divergences between the planned and the executed. In daily life, conditions change in relation to the ideal scenario, with unpredictability, unexpected behavior, complexity generates conflicts between the parties, changing the desired performance in planning the activity. It should also be noted in each function the ability to undergo variation or changes (WOLTJER, 2009).

After determining the theme, the objective of the study is defined by the scientific method, by the following steps in the construction of the work: a) literature search on themes related to systemic thinking, decision making and proactive indicators; b) adoption of theoretical model for use in process mapping; c) mapping of decision making; d) identification of bottlenecks in management processes; e) projection of leeway in decision making; f) prospecting for proactive indicators and g) optimizing the resilience level of the studied process, according to Figure 2 - Methodology of search. 
Figure 2 - Methodology of search

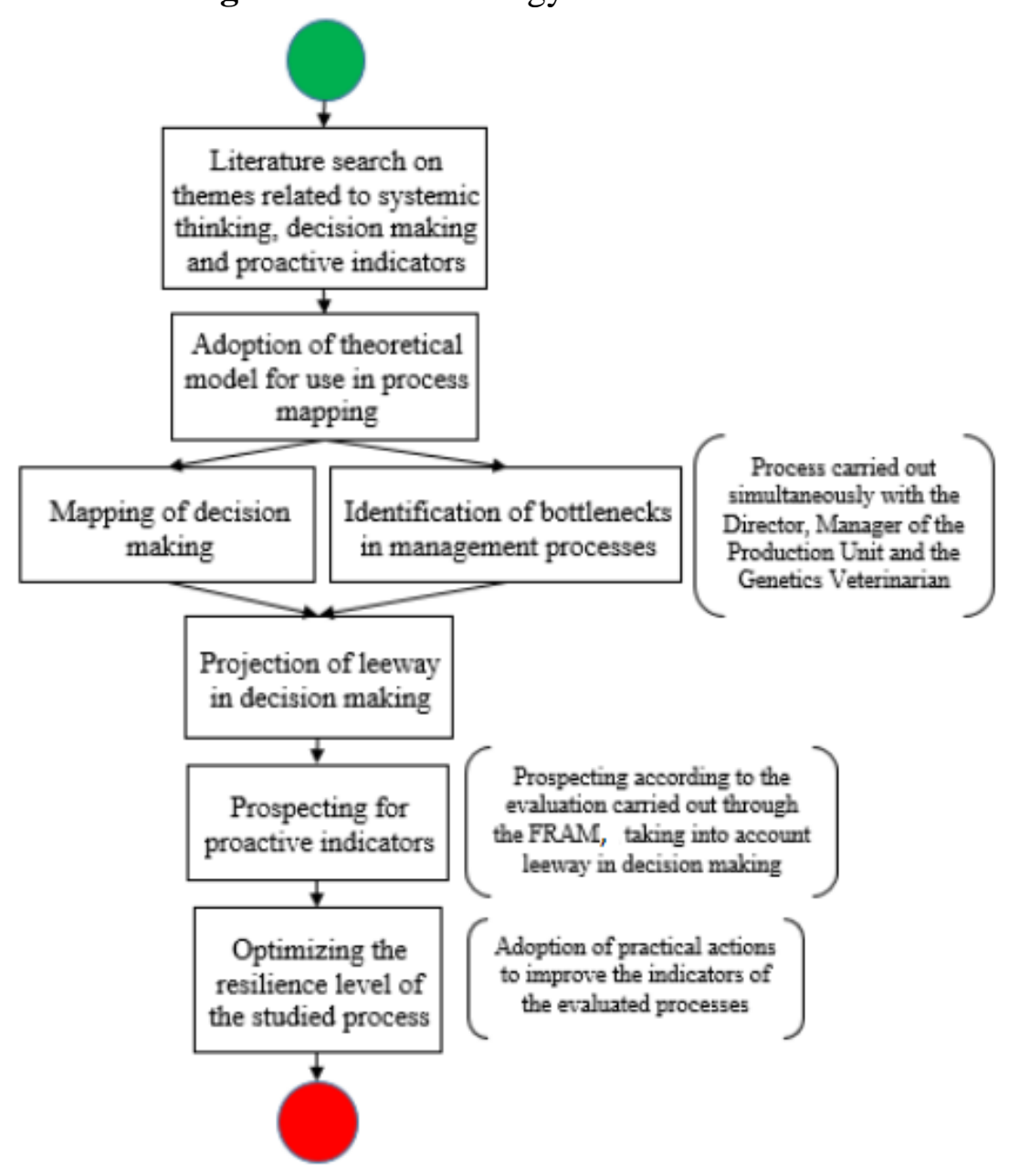

Source: Authors (2019).

The technical procedures used are based on the term action research, where the researcher analyzes and announces his objective, mobilizing the team, collectively, in the construction of new knowledge, integrating all participants in problem solving, thus providing an approximation theory and practice, which enables better acceptance of new ideas (ELIA; SAMPAIO, 2001). The study used unstructured interviews for collection and analysis, based on the aspects related to the FRAM method.

In the study by Praetorius G, et al. (2015), on modeling vessel traffic service for better understanding of operations and understanding of resilience, the methodology was conducted through data collection, consisting of two types of interviews (semi-structured, focus group) and six-hour observation at a center. FRAM was used to analyze the data and model the daily 
operations of the system and thus obtain information on the needs to successfully provide the service to the marine community.

In the studies of Pedro N. P. Ferreira and José Juan Cañas (2019), the use of FRAM was extended in a multifactorial perspective, in addition to human factors and aimed at exploring the interactions between human, organizational and technological factors. The initial steps of FRAM modeling (the job description) allowed for an abstraction of the processes and the multiple conditions under which they can be performed (in accordance with formal procedures and informal working methods). As an objective, the focus of the study is isolated on the definition of functions as something that must be accomplished in order to achieve the objectives under real working conditions. In the sequence, the conditions related to the context are introduced as potential sources of functional variability. This feature of FRAM was highlighted by the authors as fundamental in the scope of the research, as it provided the means to establish a baseline for comparisons. The expected future automation scenarios were investigated by the tool.

Thus, studies that use FRAM follow a linear line of reasoning, following Hollnagel's precepts. The ways of developing the functions of each process are specific to each activity, however, they follow a familiar structure of research and application. Thus, the present study proved to be similar in the methodological construction when compared to the Praetorius G, et al. (2015) and Ferreira, Cañas (2019) studies, when the sequences of actions performed in the methodological procedures were evaluated.

\section{RESULTS AND DISCUSSION}

The practical part of the study, carried out in a unit producing weaned piglets, was divided into 6 stages: data collection - interviews, process mapping using FRAM, action planning, projection of leeway in decision making, proposal for improvement actions and proactive indicators.

In the data collection stage, interviews were conducted with the managers (Director, Unit Manager and the Veterinarian responsible for genetics), of the piglet producing units (UPL), serving as the basis for the process mapping using the FRAM. Figure 3 highlights the six main functions highlighted in the unstructured interview with the unit manager and which are essential for the process. 
Figure 3 - Main functions of the productive cycle of the UPL
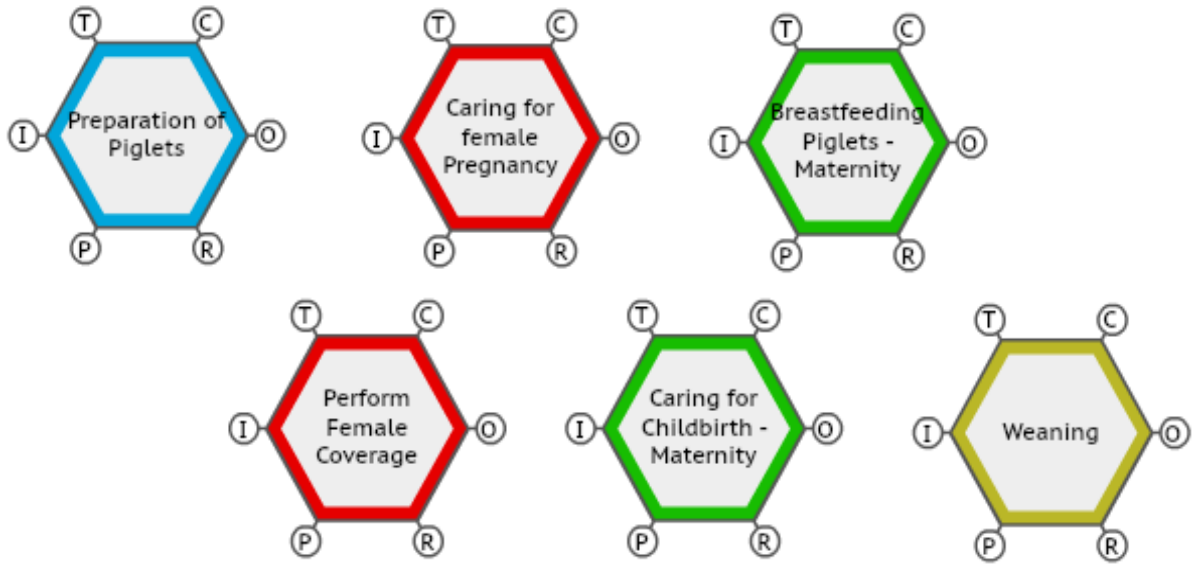

Source: Authors (2019).

In this sense, the study meets Herrera and Woltjer (2010), when it aims to capture dynamics and non-linear interdependencies, where FRAM is structured in the functions of the systems and not in physical structures. In the studies by Nouvel; Travadel; Hollnagel, (2007), Shirali; Mohammadfam, (2013) and Praetorius; Hollnagel; Dahlman, (2015) the mapping of complex systems by functions is evident, which are modeled in FRAM to understand the relationships between the steps of a process and its non-linear dynamics.

Table 03 - Description of the main functions of the productive cycle of the UPL, shows the descriptions of each function referring to Figure 03 - Main functions of the productive cycle of the UPL.

Table 3 - Description of the main functions of the productive cycle of the UPL

\begin{tabular}{l|l}
\multicolumn{1}{c|}{ Functions } & \multicolumn{1}{c}{ Description } \\
\hline Preparation of Piglets & Training and preparation for artificial insemination. \\
\hline Perform Female Coverage & Heat identification and artificial insemination of the matrices. \\
\hline Caring for female Pregnancy & Cares at the gestational period of the matrices \\
\hline Caring for Childbirth - Maternity & Cares before, during and after the calving of piglets. \\
\hline Breastfeeding Piglets - Maternity & Cares with piglets breastfeeding till the weaning period. \\
\hline $\begin{array}{l}\text { Weaning } \\
\text { Source: Authors (2019). }\end{array}$ & Sending the matrices to cover and the piglets to the nursery.
\end{tabular}

The mapping of the piglet production process at the UPL, using the FRAM model, aimed to project room for maneuver in decision making and propose improvement actions, in line with what was exposed by Wachs (2016), regarding the need for quick responses and assertive to the decision, preserving the integrity of the system and the management of 
operations. In this sense, the primary (mapped in the highlighted color model) and secondary functions of the production process were mapped, linking them in order to allow a broad understanding of all tasks and their connections to the system.

The essential functions in the piglet production process are located in two floors in the UPL where the study was carried out: Maternity Shed, where the functions "Caring for Childbirth - Maternity" and "Breastfeeding Piglets - Maternity", both in green colors, and in the Pregnancy Shed, where the functions "Perform Female Coverage" and "Caring for Female Pregnancy" are performed in red. Already the function "Preparation of Piglets", in blue, is performed in the shed of pregnancy and ensures the replacement of the squad, in which after performing the coverage of the piglet, will become an active female in the squad.

The main functions are completed with the "Weaning", highlighted in yellow in the FRAM method, which occurs at the end of each female's reproductive cycle, and begins at the maternity, with the best littered and weaning conditions, considering the variables age and weight. During pregnancy, the number of females needed to perform the coverage in the next reproductive cycle is observed.

The technological, human and organizational variables of the processes are described in this study, as they are essential in the understanding that they present performance variability. Thus, the variables can have different behaviors in order to fit a specific objective of the system, which results in unexpected events, as Hollnagel (2017) describes about the variables and their behaviors.

FRAM follows a mapping structure that includes six stages of characterization of functions. Thus, it is necessary to use techniques to elicit these functions. The present study used observation techniques and structured interviews. In this sense, it is necessary for the mapping to be performed by a professional who has full theoretical-practical understanding of FRAM and its development, in order to capture all the variables present in the process (HOLLNAGEL, 2017).

In the studies by Nouvel, Travadel, Hollnagel (2007); Hollnagel, Pruchnicki, Woltjer, Etcher (2008); Steen, Aven (2011), Belmonte, Schön, Heurley, Capel (2011); Lundblad, Speziali (2008); Sujan., Felici. (2012); Shirali, Mohammadfam (2013) and Praetorius, Hollnagel, Dahlman (2015) countless ways of eliciting the variables of the six FRAM steps were employed. Among them, the most common are observation and structured interviews. However, the following were also used in the elicitations: reports made available by 
management systems, process mapping techniques, consultation of medical records, records of the quality, safety and engineering teams.

In this study, the six main functions of the UPL are described in the following tables and figures, which allow a richer detailing of the activities that make up each of the functions and the aspects that are considered for them, as well as the existing links between the activities and better understanding of the operation of the operations of the evaluated unit. In the FRAM report, when the description of the "Downstream" aspect is allocated with the "Amount" of another function, it is not highlighted in red, reducing the bottlenecks of the Decision Making process.

For a better understanding of the production process, a table with the steps to characterize the FRAM functions, a graphical representation of the process and a brief description for each of the six main functions are presented in sequence.

Table 4 - Function: Preparation of piglets and their aspects

\begin{tabular}{l|l} 
Function & Preparation of piglets \\
\hline Description & $\begin{array}{l}\text { Training and preparation for the artificial insemination, ensuring the replacement of the } \\
\text { squad }\end{array}$ \\
\hline Aspect & Aspect description \\
\hline Inputs & New piglets \\
\hline \multirow{2}{*}{ Outputs } & Fit piglets \\
\cline { 2 - 2 } & Female piglets \\
\hline \multirow{4}{*}{ Resources } & Healthy piglets \\
\hline \multirow{3}{*}{ Control } & Eating at ease \\
\cline { 2 - 2 } & Training machine \\
\cline { 2 - 2 } & Big Farm Net information \\
\cline { 2 - 2 } & Individual record \\
\cline { 2 - 2 } & Identification tag with Baston \\
\cline { 2 - 2 } & Weight and age to cover use \\
\cline { 2 - 2 } & Preventive vaccination \\
\hline \multirow{2}{*}{ Time } & Piglets in heat \\
\cline { 2 - 2 } & Identification of the heats during training \\
\cline { 2 - 2 } & Minimum age of 210 days \\
\cline { 2 - 2 } & Body score between $135 \mathrm{~kg}$ and $155 \mathrm{~kg}$ \\
\hline
\end{tabular}

Source: Authors (2019).

Figure 4 presents graphically the functions of Table 4, Preparation of piglets and their aspects. As the graphical representation of the functions has large dimensions due to the complexity of the process and the number of activities performed, for the purpose of better visualization, a part of the graph was cut out, being presented where the connections of the main function are concentrated. 
Figure 4 - Representation with part of Mapping with FRAM: Preparation piglets function

Source: Authors (2019).

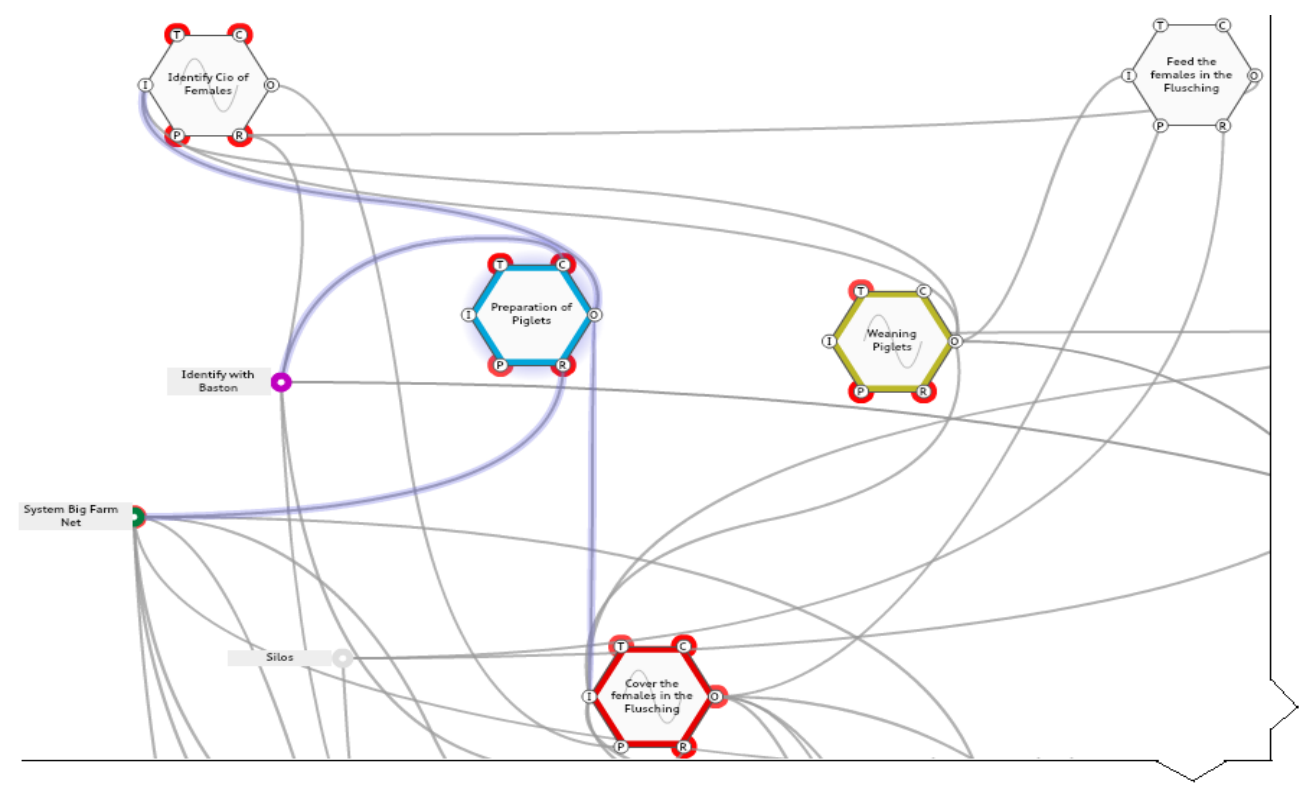

The aspects of entries determine the beginning of the process of acting in the function, in which, to carry out the Preparation of the Sows, it is necessary to receive the "Sows New" from the Headquarters. Emphasizing the prerequisites to start acting in the role, the Female needs to be healthy to start the preparation, being analyzed the body condition, history and genealogy, guaranteeing the quality of the replacement of the squad.

In industrial processes, where product standardization is an essential attribute, Almeida (2008) mentions that the compromise in efficiency and quality in the development of activities is the result of the collective construction of the parts. In this way, monitoring and adjustments in the processes are necessary so that there are no differences between the planned and the executed. To this end, FRAM adds the possibility of simulating different variations and checking where these changes will have consequences. 
The free feeding, the training machine, the automated treatment and information in the Big Farm Net System are part of the necessary resources to produce results in the Suck Preparation function. As a control of the actions carried out, an individual record, marking with a stick, is used to identify females in heat, preventive vaccination and monitoring of age and weight for use in the coverage. In terms of time, it is necessary to monitor and identify heat, be at least 210 days old and weigh between 135 and $155 \mathrm{~kg} /$ live. With these aspects in mind, the next function, "Covering Females in Flusching", is the answer.

Table 5 - Function: Perform Female Coverage and their aspects

\begin{tabular}{|c|c|}
\hline Function & Coverage of piglets \\
\hline Description & Cares in relation to coverage, ensuring the percentage of pregnant females in insemination \\
\hline Aspect & Aspect description \\
\hline \multirow[t]{4}{*}{ Inputs } & Female weaning \\
\hline & Female return of the heat \\
\hline & Female \\
\hline & Female piglets \\
\hline \multirow[t]{5}{*}{ Outputs } & Pregnant females \\
\hline & Identification of females to medicate \\
\hline & Sick females \\
\hline & Females body score recover \\
\hline & $\%$ cover \\
\hline Prerequisits & Female in heat \\
\hline \multirow{4}{*}{ Resources } & Insemination box \\
\hline & Trained inseminator \\
\hline & Male ruffian \\
\hline & Identification tag with Baston \\
\hline \multirow[t]{3}{*}{ Control } & Individual record \\
\hline & Insemination notebook \\
\hline & Number of weekly coverages \\
\hline \multirow[t]{3}{*}{ Time } & Females on heat: morning, morning, morning \\
\hline & Female piglets on heat: evening, morning, morning \\
\hline & Females on heat 6 to 7 days after weaning: morning, evening, morning \\
\hline
\end{tabular}

Figure 5 presents graphically the functions of Table 5, Perform Female Coverage function. 
Figure 5 - Representation with part of Mapping with FRAM: Perform Female Coverage function

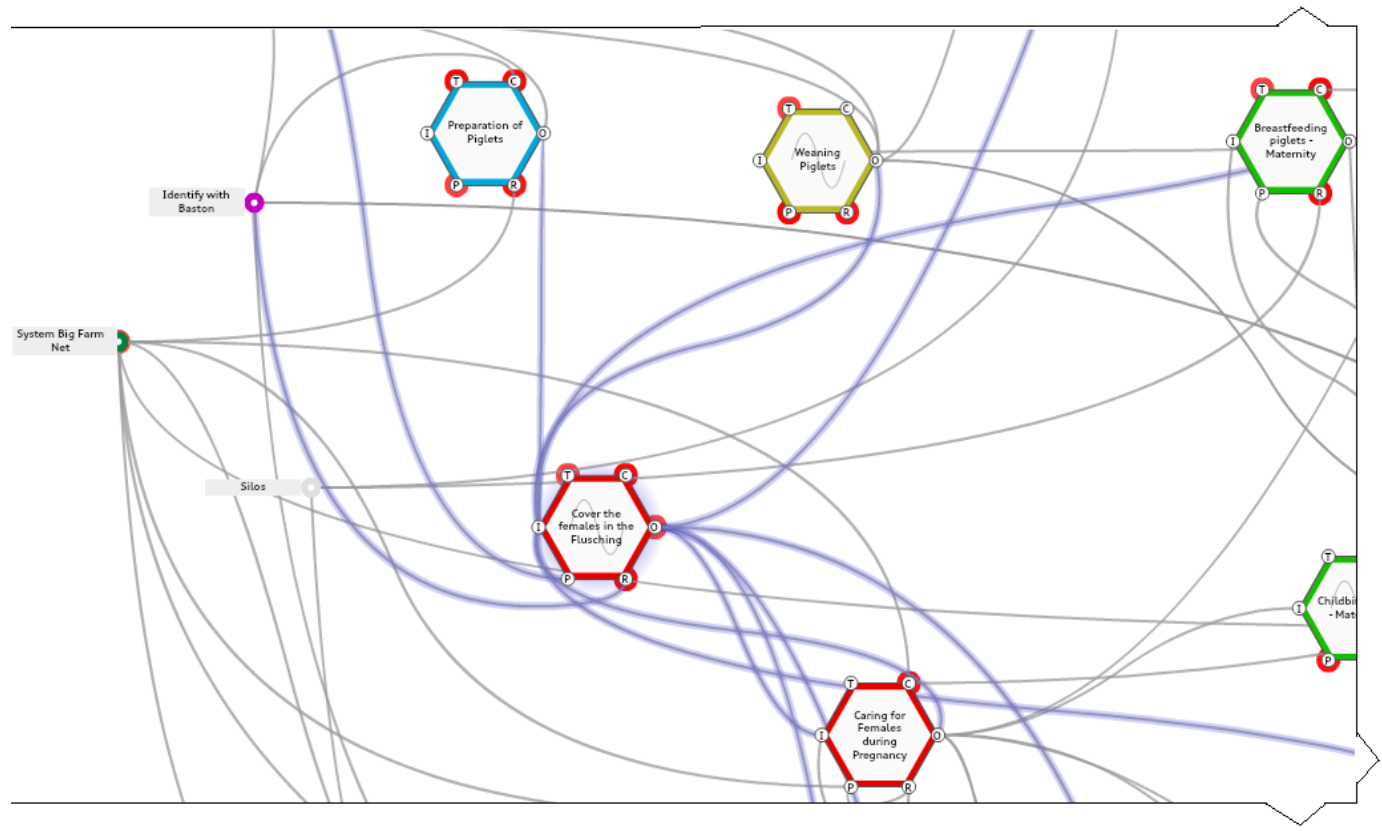

Source: Authors (2019).

In addition to the description performed by functions, the graphical representation of FRAM demonstrates the complexity of the relationships between different variables, where an output from a function can affect the input of other functions and even non-linear variables. In this sense, the dynamism, the variety, the doubts and the influences that occur between the elements of the system demand that it be shaped so that it has resilience capacity to keep it functioning (DEKKER et al., 2013). This ability to adapt to situations of conflict or transformation and to maintain operations in acceptable conditions defines resilience (HOLLNAGEL, 2011).

Following the process, in the Perform Coverage of Females function, the inputs originating from the primary functions, Weaning "Females Weaning", Preparation of Sows "Sows Sows", generates females able to carry out the coverage of the week, and meeting the prerequisite "Females in Cio" to initiate Artificial Insemination. In order to meet the preestablished percentage of coverage, the outputs of the secondary functions are taken into account, identifying estrus return "Females Retorno de Cio" and identifying abortion "Females Salta cio", which have an acceptable percentage of incidence, and already calculated for the gestational period of females during pregnancy. 
The main result of the function is "Pregnant Females", making it a necessary element to Care for Females during Pregnancy. In addition to this result, it can generate outputs as "Sick females", sent to the Medicar function, under the prerequisite of "Identification of Females to Medicate", outputs as "Females Body Score Recovery", a prerequisite to increase the volume of feed. in the function Feeding the Females in the Flusching, and output of " \% coverages" used for decision making in the process.

Table 6 - Function: Caring for Female Pregnancy and their aspects

\begin{tabular}{l|l} 
Function & Caring for female pregnancy \\
\hline Description & Cares in the preganancy period to ensure farm farrowing rate \\
\hline Aspect & Aspect description \\
\hline \multirow{4}{*}{ Inputs } & Pregnant females \\
\cline { 2 - 2 } & Healthy females \\
\cline { 2 - 2 } & Females pregnant for 110 days \\
\cline { 2 - 2 } & Furt females \\
\cline { 2 - 2 } & Abortion identification \\
\cline { 2 - 2 } & Female identification to medicate \\
\hline \multirow{5}{*}{ Prerequisits } & Healthy females \\
\cline { 2 - 2 } & Identification chip \\
\hline \multirow{4}{*}{ Resources } & Big Farm Net \\
\cline { 2 - 2 } & Big Farm Net Information \\
\cline { 2 - 2 } & Skilled professional \\
\hline Control & Big Farm Net acompanniment \\
\cline { 2 - 2 } & Individual record \\
\cline { 2 - 2 } & Reproductive losses (heat repetition, abortion, mortality and discard) \\
\cline { 2 - 2 } Sime & Pregnancy days \\
\hline \multirow{2}{*}{ Source: Authors (2019). }
\end{tabular}

Figure 6 presents graphically the functions of Table 6, Caring for Female Pregnancy and their aspects. 
Figure 6 - Representation with part of Mapping with FRAM: Caring for female Pregnancy function

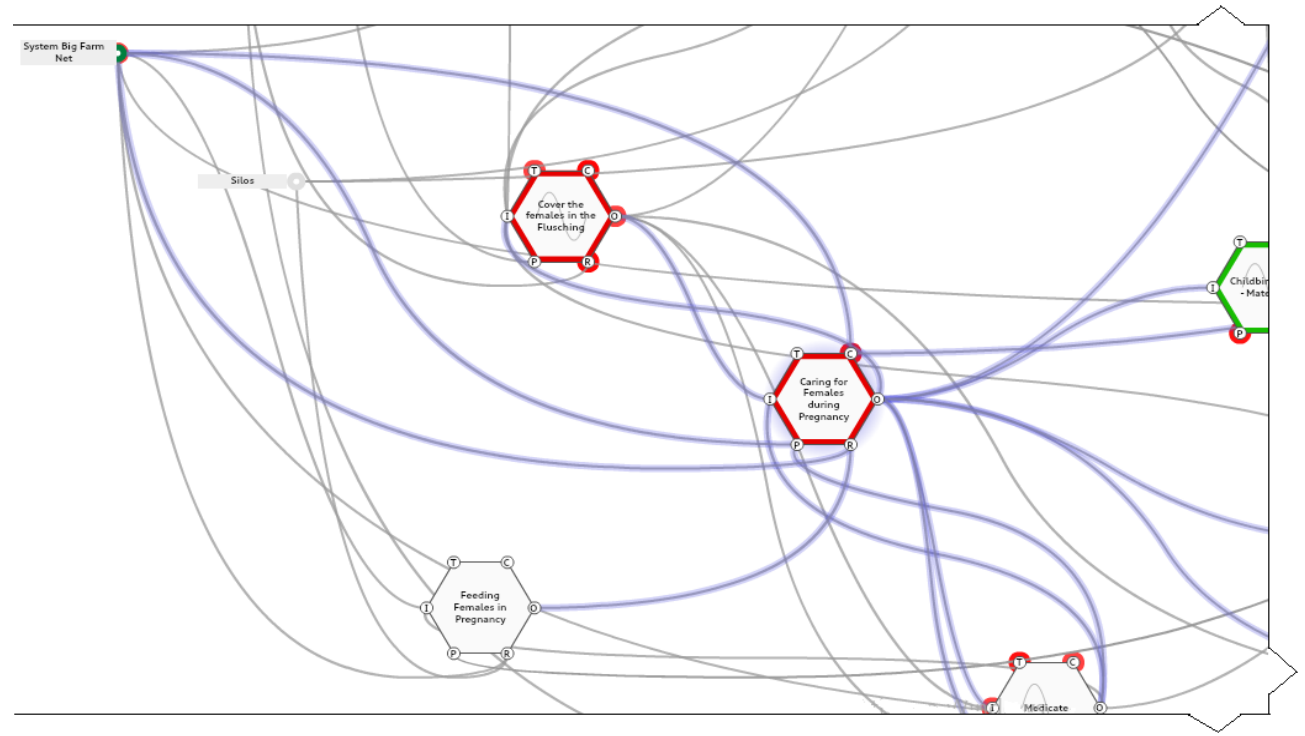

Source: Authors (2019).

The function Caring for Females during Pregnancy links care during the gestational period, carried out in an environment called "well-being", as they are collective pens, with automated feeding through individual chips in each female. Performed with 10 Big Farm Net equipment, with a capacity for 86 females per machine, which allows the monitoring of daily feeding, alteration of the feeding curve, marking and separation of the female for medication, preparation for delivery to the maternity at 110 days of gestation, body score analysis, in addition to identifying right-handed females by looking for the male housed in the individual stalls.

Care during the gestational period guarantees the rate of calving of the herd, the incidence of stillbirths and mummifieds at birth, the health of the females providing conditions to breastfeed the litter until weaning, being the stage with the greatest number of days in the reproductive cycle of the females active squad. The main and desired result of the function, is giving at the end of the stage, with "Females 110 days of Pregnancy", which will be sent to the Care function in Childbirth.

Table 7 - Function: Caring for Childbirth - Maternity and its aspects

\begin{tabular}{l|l} 
Function & Caring for Childbirth - Maternity \\
\hline Description & Cares before, during and after the birth \\
\hline Aspect & Aspect description \\
\hline Inputs & Females 110 days pregnant \\
\hline Outputs & Females with piglets
\end{tabular}




\begin{tabular}{l|l}
\multirow{3}{*}{ Prerequisits } & Adequate temperature \\
\cline { 2 - 2 } & Termic floor on \\
\hline \multirow{4}{*}{ Resources } & Drying poder \\
\cline { 2 - 2 } & Termic floor on \\
\cline { 2 - 2 } & Skimmer Lighting \\
\cline { 2 - 2 } & Food suplement \\
\cline { 2 - 2 } & Reduction in prenatal feeding \\
\cline { 2 - 2 } & Gradual increase in postpartum feeding \\
\cline { 2 - 2 } Control & Birth help, with massages, in the vulva and breast tract \\
\cline { 2 - 2 } & Intervation with medication or touch if difficult in birth \\
\hline Time & Calving rate \\
\cline { 2 - 2 } & Average of live births and birth weight \\
\hline Sirths must occur between 112 and 117 days of pregnancy
\end{tabular}

Source: Authors (2019).

Figure 7 - Representation with part of Mapping with FRAM: Caring for Childbirth Maternity

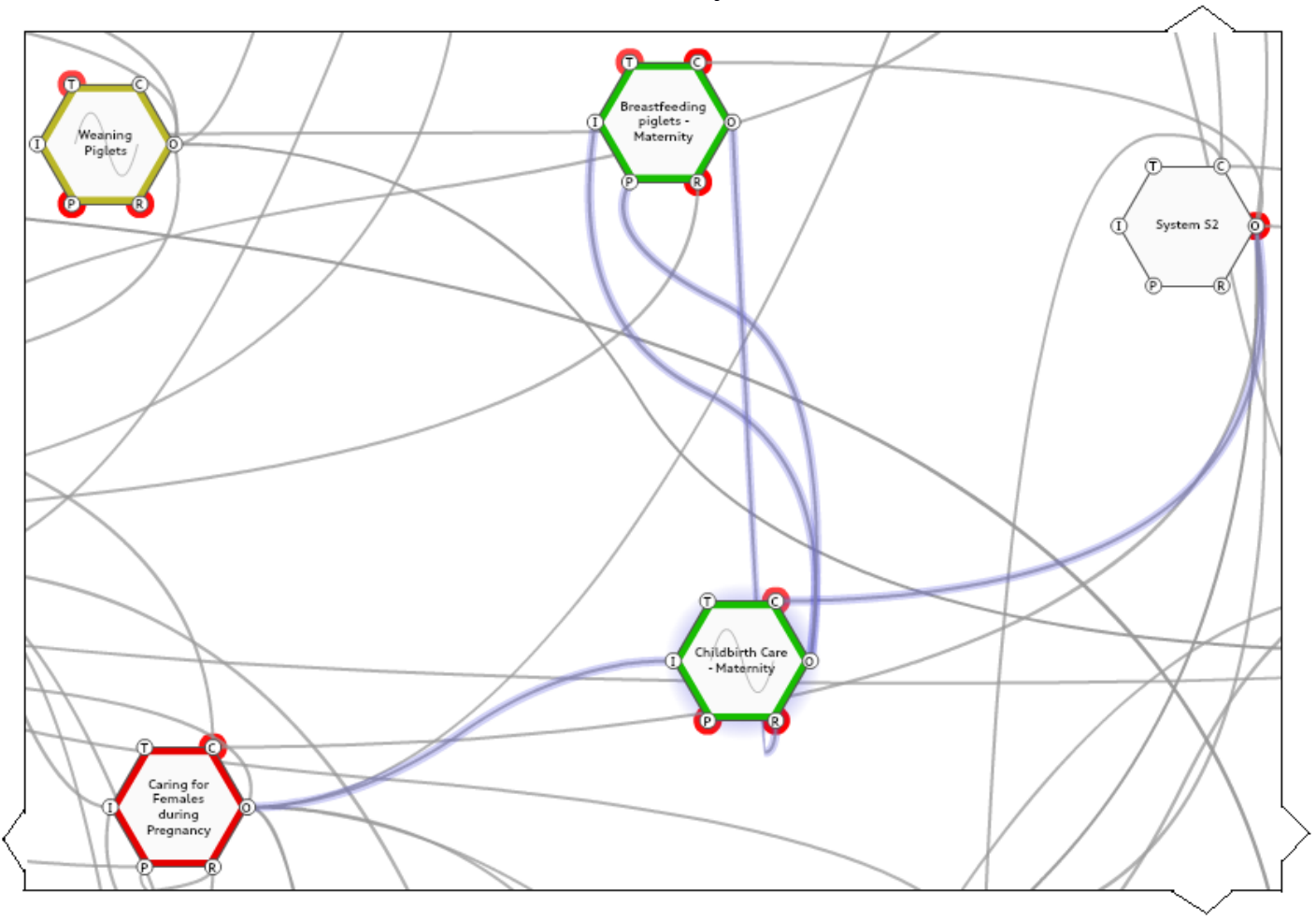

Source: Authors (2019).

At this stage of the process, care is taken to prepare the females to give birth, which are in feeding, signs related to the health of the females, and conditions for the peaceful and natural birth. Table 7 highlights the resources reported for the prepartum, delivery and postpartum period, ensuring that the goal of Live Births per Female is achieved, the uniform intake of colostrum in the litter, the monitoring of the first days of life of each piglet. In this stage, the intrinsic monitoring given to the "mother females" guarantees her care for the litter. 
After the third day of birth, the application of iron, vitamin $\mathrm{E}$ is cut off the tail of the litter and, from this action, the new stage of care performed in the maternity ward, the "Breastfeeding the Piglets - Maternity" function, begins.

Table 8 - Function: Breastfeeding Piglets - Maternity and its aspects

\begin{tabular}{l|l} 
Function & Breastfeeding Piglets - Maternity \\
\hline Description & Postpartum cares till piglet weaning \\
\hline Aspect & Aspect description \\
\hline Inputs & Females with piglets \\
\hline \multirow{3}{*}{ Outputs } & Females with weaned piglets \\
\cline { 2 - 2 } & Females milk mothers \\
\hline \multirow{4}{*}{ Resources } & Females with piglets \\
\cline { 2 - 2 } & Adequate nutrition \\
\cline { 2 - 2 } & Quality and abundance of water \\
\cline { 2 - 2 } & Litter uniformity \\
\cline { 2 - 2 } & Quantity of piglets with number of tits \\
\cline { 2 - 2 } & Milk mother for refused \\
\cline { 2 - 2 } & Milk mother for over birth piglets \\
\cline { 2 - 2 } & Quality food \\
\cline { 2 - 2 } & Average of weaned and weight of weaning \\
\cline { 2 - 2 } Control & Control of used medication \\
\cline { 2 - 2 } & Monitoring the uniform development of litter \\
\cline { 2 - 2 } & Lactation days \\
\hline Time & Minimum age of 28 days
\end{tabular}

Fonte: Autores (2019).

Figure 8 - Representation with part of Mapping with FRAM: Breastfeeding Piglets Maternity

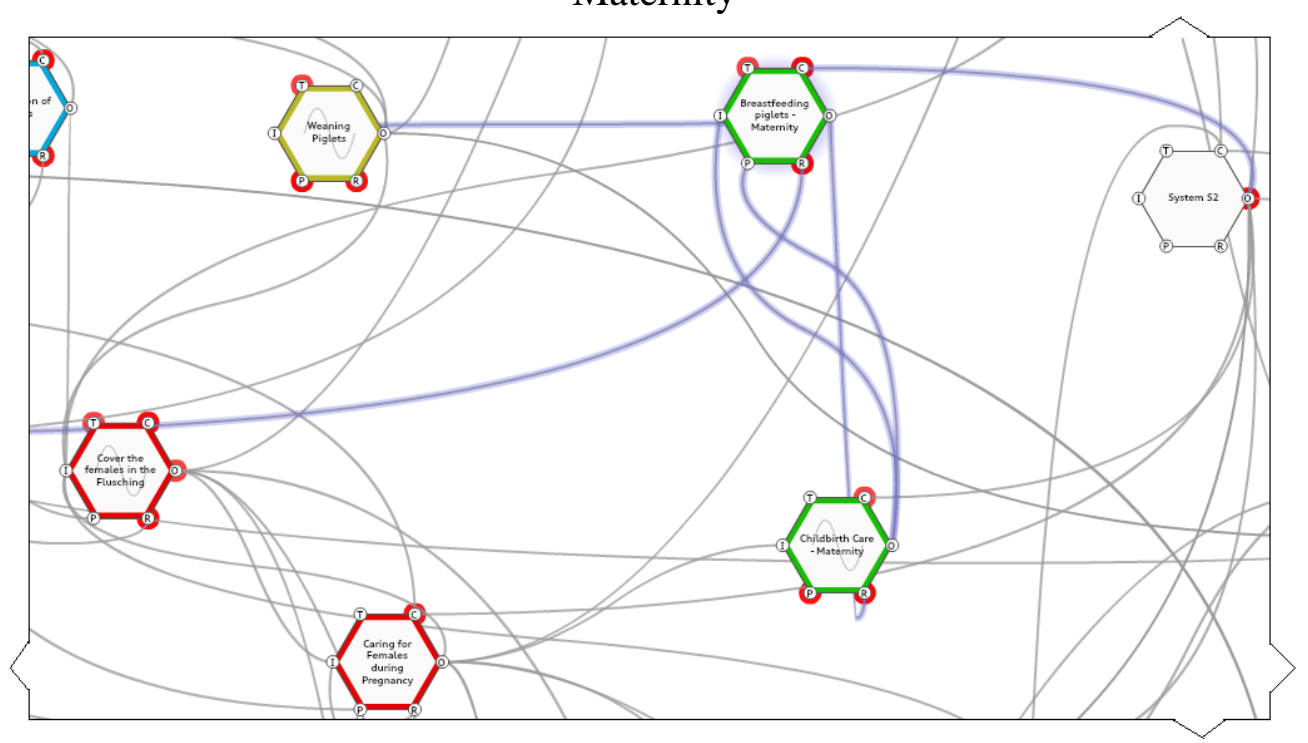

Source: Authors (2019). 
Breastfeeding the Piglets, which will last for the next 25 days of life, described in Table 8 and represented in Figure 8 in Mapping with FRAM. In this regard, the use of resources, accompanied by daily controls, will provide, in due time, the "exit" results of the function that corresponds to "Females with weaned piglets", giving rise to the Weaning of Piglets function, or "Females Mother of Milk", which will return as a resource in the Caring for Childbirths function, to breastfeed a new litter created from piglets that were discarded during breastfeeding time, or leftovers generated by the number of live births in relation to the number of viable ceilings per females.

Adequate nutrition, based on quality lactation ration, provides a healthy litter with good daily weight gain, and it is difficult to refuse piglets or diarrhea during the breastfeeding cycle.

Table 9 - Function: Weaning and its aspects

\begin{tabular}{l|l} 
Function & Piglets weaning \\
\hline Description & Piglets are taken to nursery and mothers to coverage \\
\hline Aspect & Aspect description \\
\hline \multirow{2}{*}{ Onputs } & Females weaned \\
\cline { 2 - 2 } & Fit females \\
\cline { 2 - 2 } & Piglets weaning \\
\cline { 2 - 2 } & Age \\
\hline \multirow{4}{*}{ Prerequisits } & Pow productivity \\
\cline { 2 - 2 } & Piglets ideal weight \\
\cline { 2 - 2 } & Quantity off emales for weekly coverage \\
\cline { 2 - 2 } & Weekly weaned piglets goals \\
\hline Resources & Individuals stalls at maternity rooms \\
\cline { 2 - 2 } & Room available to receive females at the end of pregnancy \\
\hline Control & Piglets weaning \\
\hline Time & Average of 28 days \\
Fonte: Autores (2019).
\end{tabular}


Figure 9 - Representation with part of Mapping with FRAM: Weaning - Maternity

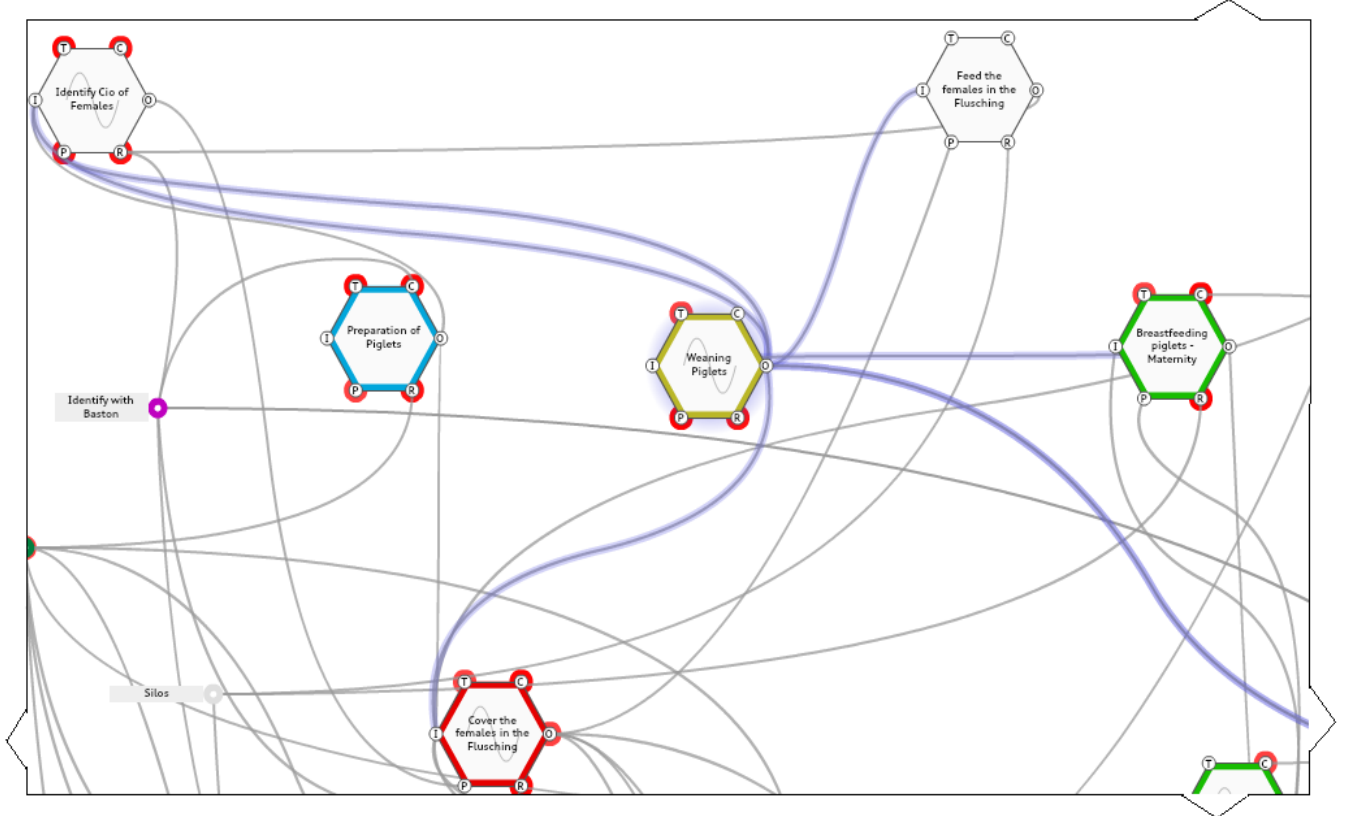

Source: Authors (2019).

Table 9, Weaning Piglets, lists the aspects related to the last function associated with the reproductive cycle within a Weaning Producing Unit (UPD). In this function, the entry is connected to "Females with breastfeeding readings of maternal function, and generated as videos:" Weaning from milks ", Fit Females ", Females Weaning ”, Age of females "and" Females with low performance".

The description of the process functions by the FRAM, in a UPL, shows that dozens of variables must be considered for the process to have the desired results. These processes are connected by functions and variables that are transversal to human, technological and infrastructure resources. The interactions between hundreds of variables define the Unit's success. In line with the above, Rassmussen's (1997) studies suggest that complex systems are subject to different pressure vectors (economic, security, audit, quality). Economic pressure can bring instability to quality aspects, for example. As the production systems are dynamic and susceptible to internal and external variables, the stability of your process is at risk. Hollnagel et al. (2008) suggests, therefore, that measures that provide an application of resilience engineering be taken.

\subsection{Projecting leeway in decision making}

Through the mapping of the main functions and their aspects, as well as the understanding of the relationships between the resources of the UPL production process 
through the FRAM, it was possible to obtain a holistic view of the organization and its stages. In this sense, Fogaça (2015) points out that improving processes requires planning, integration, analysis and management, the result of process management directly linked to the systemic view, resulting in efficiency and added value in the delivery of products or services. In this way, the holistic view of the processes brings several improvements, which, added to the Lean philosophy, brings promising results (DÜES et al. 2013; GALEAZZO et al. 2014).

The study made it possible to verify that there is a high level of complexity of activity and decision making in view of numerous variables that interfere with the desired results. In this scenario, Portela (2016) indicates that in processes where the decision must consider numerous factors, resilience is necessary, in order to sustain unforeseen circumstances, minimizing significant organizational problems, making it more stable, safe and qualified.

In this sense, the managerial decisions to be taken were highlighted in the unstructured interviews directed to the manager and the unit owner, seeking through FRAM mapping the analysis of choice compatibility, the standardization of procedures and the holistic view of the links between functions throughout the process.

The importance of complimenting or studying with secondary functions was identified, by contributing with the main aspects of entry, control, prerequisite resources and function time. Secondary functions, created to complement the study and map the process with a holistic view of operations, linking sales with entries in other functions, as differences in the number of coupling entries, generate tests in the process creating bottlenecks in the management of operations, which according to Hollnagel (2012), it can generate instabilities and undesirable results in the process.

To better illustrate decision making, the "Decision Making" function was created, based on the technical action research procedure for its applicability.

Table 10 - Function: Decision making and its aspects

\begin{tabular}{l|l} 
Function & Decision making \\
\hline Description & $\begin{array}{l}\text { Managerial functions that require decision making based on Functional Resonance } \\
\text { Analysis }\end{array}$ \\
\hline Aspect & Aspect description \\
\hline \multirow{5}{*}{ Inputs } & Feverage \\
\cline { 2 - 2 } & Female food consumption per day \\
\cline { 2 - 2 } & Piglets food consuption \\
\cline { 2 - 2 } & Average age of weaning \\
\cline { 2 - 2 } & Piglets death at the period \\
\cline { 2 - 2 } & Calving rate
\end{tabular}




\begin{tabular}{l|l}
\multirow{4}{*}{ Outputs } & Best decision making \\
\cline { 2 - 2 } & Action plan \\
\cline { 2 - 2 } & Ideal delivery \\
\hline \multirow{4}{*}{ Prerequisits } & Working with the available information \\
\cline { 2 - 2 } & Working with people managemant \\
\cline { 2 - 2 } & Process quality \\
\cline { 2 - 2 } & Trustable information \\
\hline \multirow{5}{*}{ Resources } & Daily weight gain per \\
\cline { 2 - 2 } & Weaned average \\
\cline { 2 - 2 } & Birth live average \\
\cline { 2 - 2 } & Weaned per female per year \\
\cline { 2 - 2 } & Weaning/coverage break \\
\cline { 2 - 2 } & Non productive days \\
\hline Control & DNP analysis - heat repetition \\
\cline { 2 - 2 } & DNP analysis - discard of pregnant \\
\cline { 2 - 2 } & DNP analysis - empty discard \\
\cline { 2 - 2 } & DNP analysis - IDC \\
\cline { 2 - 2 } & Mortality analysis \\
\hline Time & Delivery of the ideal age lot (28 days) \\
\cline { 2 - 2 } & Delivery of the ideal lor per week (612 weaned) \\
\hline
\end{tabular}

Source: Authors (2019).

After analyzing the results of other functions, you can link the Control, Prerequisite, Time and Resources aspects of the "Make Decisions" function with the visualizations of the primary and secondary functions of the process. As Exits, highlighted in the function, emphasize points to be executed in the search for improvement of execution, and are based on the main aspects of the process.

\subsection{Proposed improvement actions}

Based on the outputs resulting from the FRAM Decision Making function, some process improvement actions represented by $5 \mathrm{~W} 2 \mathrm{H}$ have been proposed to aggregate information in decision making. In this context, Fogaça (2015) considers that the analysis of functional resonance contributes to the understanding and identification of bottlenecks and the need to streamline decision making. 
Table 11 - Proposed improvement actions

\begin{tabular}{c|c} 
Action & Description \\
\hline Action 1 & Map of production in the information managemant installation; \\
\hline Action 2 & $\begin{array}{r}\text { Using the model of weekly alignment at the reunions with the team, to define action that } \\
\text { will be adressed during the week; }\end{array}$ \\
\hline Action 3 & Assemple the diagnostic tree to help with the best choices to be made; \\
\hline Action 4 & $\begin{array}{c}\text { Reduce the variability of the coverages to assure homegeneity of weekly inseminations and } \\
\text { of the childbirth; }\end{array}$ \\
\hline Action 5 & Use the weaning index/Coverage at the female discard; \\
\hline Action 6 & Discard at the individual record the possible discard female; \\
\hline $\begin{array}{c}\text { Action 7 } \\
\text { Source: }\end{array}$ & Increase the availability of food of piglets in preparation.
\end{tabular}

Source: Authors (2019).

The Action Plan adopted according to Table 12 below was based on the $5 \mathrm{~W} 2 \mathrm{H}$ tool, detailing the proposed actions to improve the process, referencing the other outputs of the "Decision Making" function. 
Table 12 - Action Plan based on the 5W2H

\begin{tabular}{|c|c|c|c|c|c|c|c|c|}
\hline & $\oplus$ & $\omega$ & & $N$ & & & $\leftarrow$ & $z_{A}$ \\
\hline & 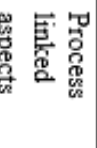 & 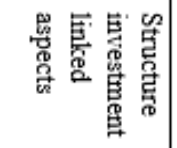 & & & & 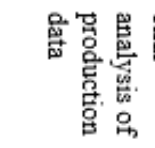 & 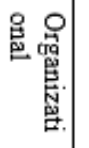 & 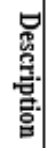 \\
\hline 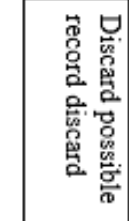 & 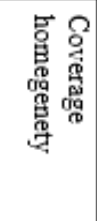 & 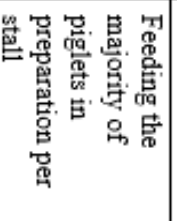 & 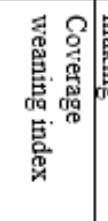 & 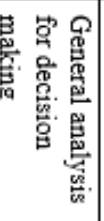 & 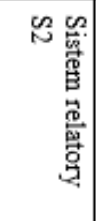 & 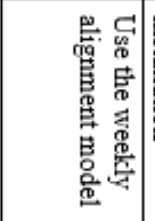 & 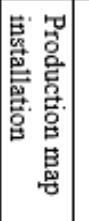 & 部 \\
\hline 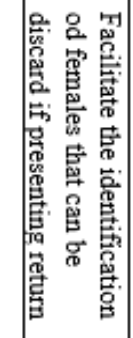 & 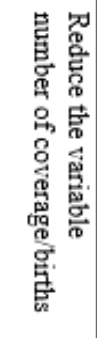 & 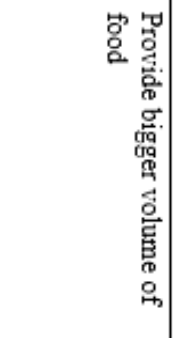 & 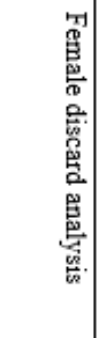 & 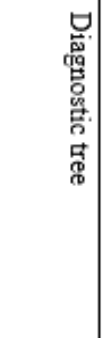 & 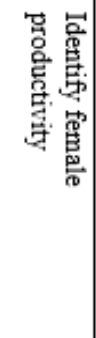 & 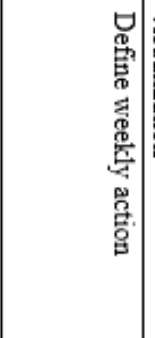 & 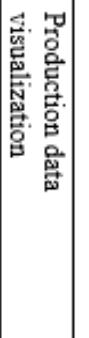 & : \\
\hline 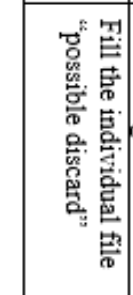 & 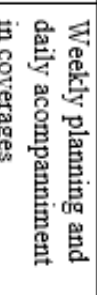 & 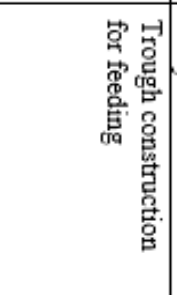 & 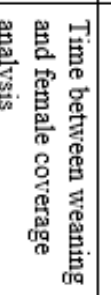 & 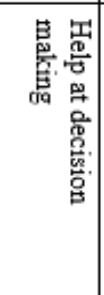 & 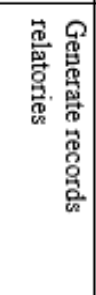 & 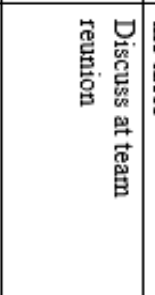 & 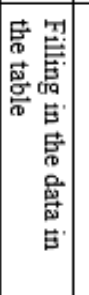 & 彭 \\
\hline 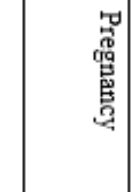 & 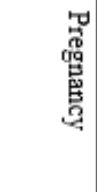 & 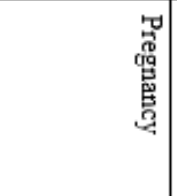 & 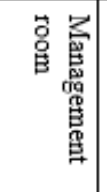 & 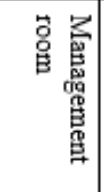 & 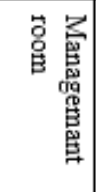 & 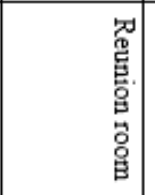 & 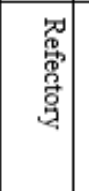 & 䇏 \\
\hline 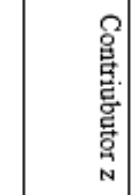 & 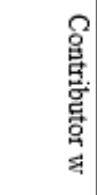 & 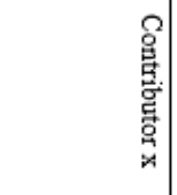 & 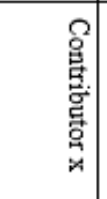 & 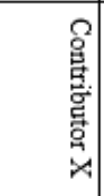 & 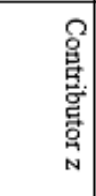 & 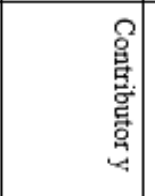 & 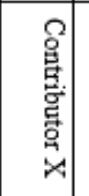 & 悹 \\
\hline 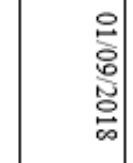 & 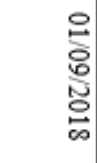 & 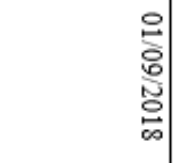 & 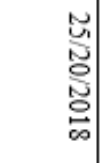 & 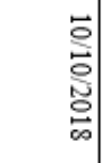 & 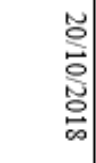 & 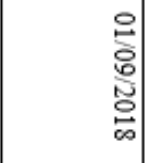 & 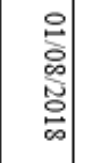 & 部 \\
\hline 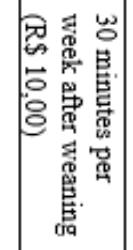 & 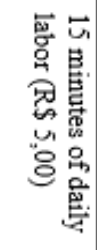 & 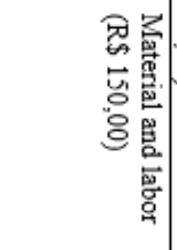 & 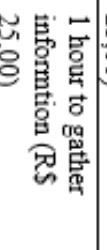 & 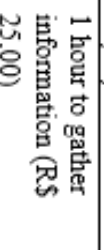 & 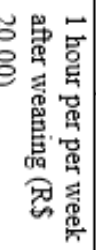 & 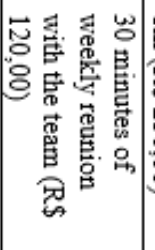 & 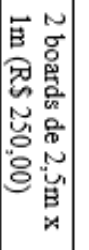 & 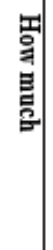 \\
\hline
\end{tabular}

Source: Authors (2019). 


\subsection{Proactive indicators}

Using the results of the "Action Plan", the "Decision Making" function was restructured, linking the new aspects described in the function. The aspects related to decision making were allocated to other functions that have the requested data, but were not used or had not been informed in the interviews conducted at the beginning of the study.

The analysis of the FRAM method allows the visualization of the number of connections that occur in the process, which may interfere with the primary functions, and consequently the decision making function.

The analysis of the FRAM method allows visualizing the number of connections that occur in the process, and that can interfere with the primary functions and, consequently, with the decision-making function. A Figure 10 shows, through FRAM, a process of complexity and as gaps with the possibility of alteration and bottlenecks in the process linked to the decision decision.

Figure 10 - Representation with part of Mapping of the FRAM and the Decision Making links

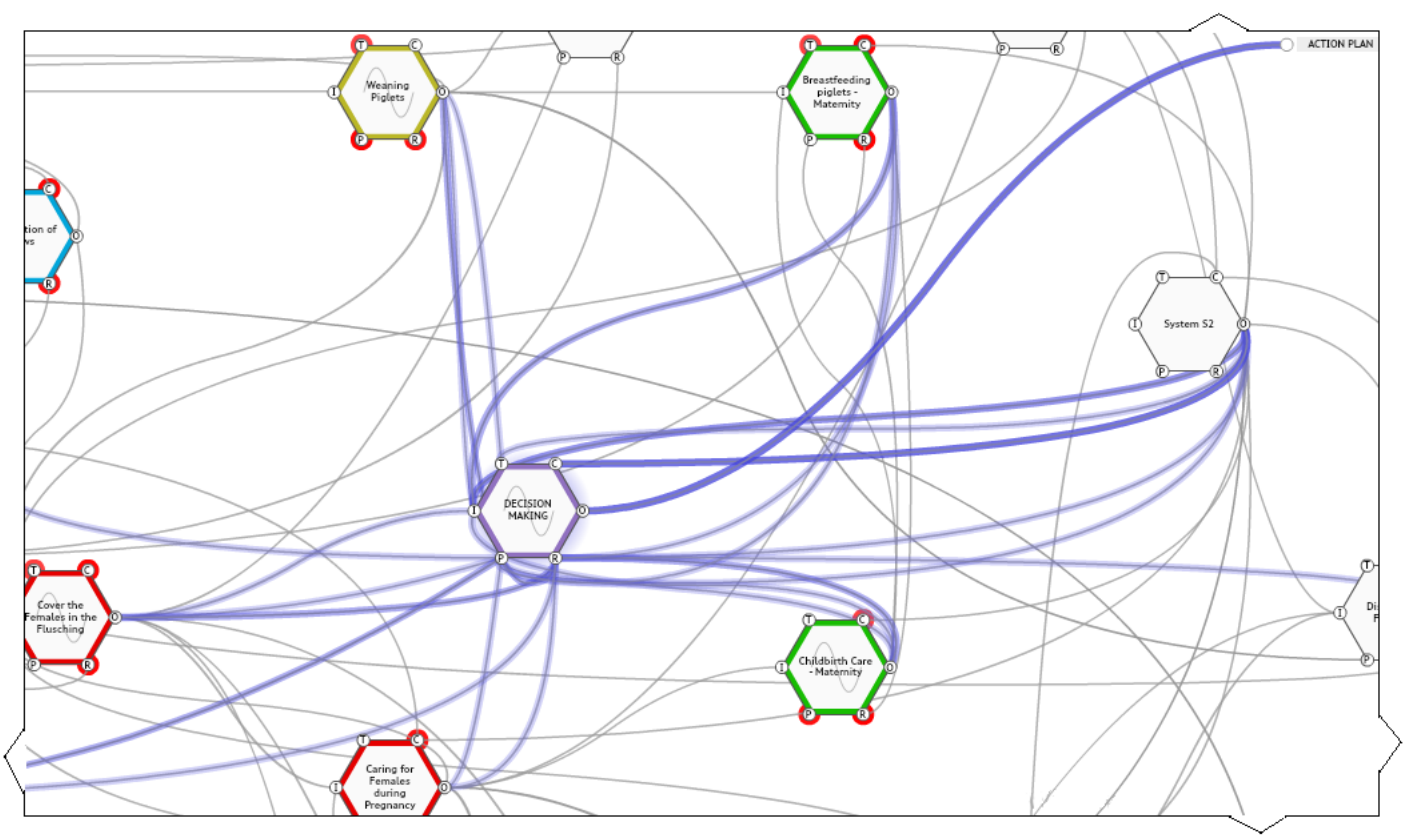

Source: Authors (2019). 


\section{CONCLUSIONS}

The mapping of the functions in the Weaning Piglet Production Unit, using the FRAM model, allowed to identify and analyze the aspects that influence decision making. When establishing links with the other functions of the process, the aspects that contribute to changes in the result were identified, allowing for a margin of error in operations (human), in the system (technological) or in management (organizational).

The mapping of the process with aspects related to each function provided the reflection of actions that would cooperate with the unit manager in defining the best decision to be made based on the structure and the degree of importance in the system used. FRAM allows you to increase the degree and type of variability, allowing you to view the function with the greatest number of variables. Coupling between functions turns simple actions into process constraints. The team's involvement in the application of the study, provided a clearer perception of the process, contributing to the fulfillment of the objectives and goals, increasing bonus gains for employees.

Functional resonance allowed the visualization of operations in a macro scope and led to rethinking each function of the process, based on improvement actions. The ability to react to the circumstances presented, seeking solutions in lived experiences and acquired knowledge, generated a resilient team, with collectors capable of acting against adverse situations generated by the system, generating satisfactory results through the actions proposed in the study, as well as allowing to map the process to facilitate operational actions and optimize results.

In the context of the present study, research allows the development of contributions in the scientific, theoretical and managerial spheres of the study under a bias of an applied nature in a highly complex process and interdependent on numerous process variables, within a complex socio-technical system. In the scientific and theoretical sphere, it was found that numerous variables applied in a practical context need to be assisted by software such as FRAM, which allows to identify variability and add unexpected events and thus, work with event simulation, with some limitations. In the managerial sphere, it was possible to develop resilient actions that allow the processes to become more reliable.

This article leaves as a legacy for future research the method for identifying homeostatic functions and broadening the agents' view of the main process variables. 
Although in ideal situations all functions should have space for maneuverability and, thus, guarantee the resilience of the system to the variability of process phenomena, for economic and technical reasons this is generally not possible.

Following the line of development of this article, it is suggested as a possible theme for future work, the development of criteria to list which functions most affect the process, as well as practical applications of FRAM in industrial processes of different segments, and thus be able to evaluate practical results between different industry segments.

\section{References}

ADOLPHE, L., ROUSVAL, B., Towards an integrated decision process of sustainable urban projects. In L. Bragança, M. Pinheiro, S. Jalali, R. Mateus, R. Amoêda, and M. C. Guedes (Eds.), Portugal SB07. Sustainable Construction, Materials and Practices-Challenge of the Industry for the New Millennium (pp. 418-425). Amsterdam: IOS Press 2007.

ALMEIDA, I. M. Análise de barreiras e o modelo de ressonância funcional de acidentes de Erik Hollnagel, Departamento de Saúde Pública da Faculdade de Medicina de Botucatu. Unesp, São Paulo, 2008.

BEHR, A. Gestão da biblioteca escolar: metodologias, enfoques e aplicação de ferramentas de gestão e serviços de biblioteca: Ci. Inf., Brasília, v. 37, n. 2, 2008.

BELMONTE, F.; SCHÖN, W.; HEURLEY, L.; CAPEL, R. Interdisciplinary safety analysis of complex sociotechnological systems based on the functional resonance accident model: An application to 30 railway trafficsupervision. Reliab Eng Syst Saf , v. 96, p. 237-249, 2011.

BRUM, T. C. Oportunidades da aplicação das ferramentas de /gestão na avaliação de políticas públicas: O Caso da Política Nacional de Resíduo Sólidos para a Construção Civil. UFJF, Juiz de Fora, 2013. Disponível em <http://www.ufjf.br/ep/files/2014/07/2012_3_Tarcisio.pdf>. Acesso em 20 out.2018.

CAMERON, I.; MANNAN, S.; NÉMETH, E.; PARK, S.; PASMAN, H.; ROGERS, W.;SELIGMANN, B. 2017. Process hazard analysis, hazard identification and scenario definition: Are the conventional tools sufficient, or should and can we do much better? Process Safety and Environmental Protection, v. 110, p. 53-70, 2017.

COELHO, T. P. C; COSTA, L.; PILATTI, L. A. Gerenciamento de Processos de Negócios: Uma visão holística. In: SIMPÓSIO DE ENGENHARIA DE PRODUÇÃO, 8, 2006. Anais... XIII SIMPEP - Bauru, SP, Brasil, 2006. 
COLligAN, L.; HOLLNAGEL, E.; HOUNSGAARD, J. FRAM - the Functional Resonance Analysis Method - a handbook for the practical use of the method; First edition, 2014; Disponível em <www.centerforkvalitet.dk/framhandbook>. Acesso em 31 set. 2017.

DEAKIN, M.; HUOVILA, P.; RAO, S.; SUNIKKA, M.; VREEKER, R. The assessment of sustainable urban development. Building Research \& Information, v. 30, n. 2, p.95-108, 2002.

DEKKER, S. Failure to adapt or adaptations that fail: contrasting models on procedures and safety. Applied Ergonomics, v.34, p. 233-238. 2003.

DEKKER, S. Drift into failure: from hunting broken components to understanding complex systems. Ashgate, Burlington, 2011. Disponível em <https://epdf.tips/queue/driftinto-failure-from-hunting-broken-components-to-understanding-complex-syste.html> Acesso em: 16 mai. 2018.

DÜES, C. M.; TAN, K. H.; LIM, M. Green as the new Lean: how to use Lean practices as a catalyst to greening your supply chain. Journal of Cleaner Production, v.40, p.93-100. 2013.

ELIA, M.F.; SAMPAIO, F.F. Plataforma Interativa para Internet: Uma proposta de PesquisaAção a Distância para professores. In: SIMPÓSIO BRASILEIRO DE INFORMÁTICA NA EDUCAÇÃO, 11, 2001. Anais...SBIE, 2001.

ELKINGTON, J. Enter the triple bottom line. The triple bottom line, Routledge. 2013.

FOGAÇA, L, B. Tomada de decisão e equilíbrio de metas conflitantes no gerenciamento de interrupções de voo em empresa de transporte aéreo regular. PUC, Porto Alegre, 2015. Disponível em <http://hdl.handle.net/10923/7094>. Acesso em 20 ago. 2017.

GALEAZZO, A.; FURLAN, A.; VINELLI, A. Lean and green in action: interdependencies and performance of pollution prevention projects. Journal of Cleaner Production, v. 85, n. 12, p. 1991-1200, 2014.

GIL, A. C. Como elaborar projetos de pesquisa. 4. ed. São Paulo: Atlas, 2008.

GONÇALVES, J. E. L. As empresas são grandes coleções de processos. RAE - Revista de Administração de Empresas, v. 40, n. 1, 2000.

HAAPIO, A. Towards sustainable urban communities. Environmental Impact Assessment Review, v. 32, n.1, p. 165-169. 2012. 
HAMMER, M.; CHAMPY, J. Reengenharia: revolucionando a empresa, em função dos clientes, da concorrência e das grandes mudanças da gerência. Tradução Ivo Korytowski. 29. ed. RJ: Campus, 1999

HERRERA, IA.; HOLLNAGEL, E.; HABREKKE, S. Proposing safety performance indicators for helicopter offshore on the Norwegian Continental Shelf. PSAM 10 - Tenth Conf. Probabilistic Saf. Assess. Manag., 2010, p. 10.

HERRERA, IA.; WOLTJER, R. Comparing a multi-linear (STEP) and systemic (FRAM) method for accident analysis. Reliab Eng Syst Saf , v.95, p. 1269-1275, 2010.

HOLLNAGEL, E.; PRUCHNICKI, S.; WOTJER, R.; ETCHER, S. Analysis of Comair flight 5191 with the functional resonance accident model. 8th Int Symp Aust Aviat Psychol Assoc 2008:8 pages.

HOLLNAGEL, E.; WOODS, D. D.; LEVESON, N. Resilience engineering: concepts and precepts. Burlington, USA: Ashgate; 2006.

HOLLNAGEL, E. FRAM: the functional resonance analysis method: modelling complex socio-technicalsystems. CRC Press. 2017

HOLLNAGEL, E. FRAM: the Functional Ressonance Analysis Method - modelling complex socio-technical systems. Burlington: Ashgate. 2012.

HOLLNAGEL, E. The ETTO principle: efficiency-thoroughness trade-off, why things that go right sometimes go wrong. Farnham, 2009.

HOLLNAGEL, E.; PRUCHNICKI, S.; WOLTJER, R. Análise de Comair Ight 5191 com o modelo de acidente de ressonância funcional. In: SIMPÓSIO INTERNACIONAL DO AUSASSOCIAÇÃO DE PSICOLOGIA DA AVIAÇÃO DE TRALIAN,8, 2008. Anais...Sydney, Austrália, 2008. Disponível em <hal- 00614254>. Acesso em 05 set. 2017.

LAKATOS, E. M.; MARCONI, M. A. Fundamentos metodologia científica. 4.ed. São Paulo: Atlas, 2001.

LEVESON, N. A new accident model for engineering safer systems. Safety Science, v.42, n.4, p. 237-270. 2004.

LUNDBLAD, K.; SPEZIALI, J. FRAM as a risk assessment method for nuclear fuel transportation. Int Confererence Work Saf 2008.

NEWMAN, L.; DALE, A. The role of agency in sustainable local community development. Local Environment, v.10, n.5, p. 477-486. 2005. 
NOUVEL, D.; TRAVADEL, S.; HOLLNAGEL, E. Introduction of the Concept of Functional Resonance in the Analysis of a Near-Accident in Aviation. 33rd ESReDA Semin. Futur. challenges Accid. Investig., 2007, p. 9 pages.

OULD, M. A. Business Process Management: A rigorous approach. Florida: Meghan-Kiffer Press, 2005.

PATRIARCA, R.; BERGSTRÖM, J.; DI GRAVIO, G. Defining the functional resonance analysis space: Combining Abstraction Hierarchy and FRAM. Reliability Engineering and System Safety, v.165, p.34-46, 2017.

PATRIARCA, R.; DI GRAVIO, G.; COSTANTINO, F.; TRONCI, M. The Functional Resonance Analysis Method for a systemic risk based environmental auditing in a sinter plant: A semi-quantitative approach. Environmental Impact Assessment Review, v.63, p.72-86, 2017.

PATRIARCA, R.; DI GRAVIO, G.; COSTANTINO, F. A Monte Carlo evolution of the Functional Resonance Analysis Method (FRAM) to assess performance variability in complex systems. Safety Science, v. 91, p. 49-60, 2017.

PEDRO, N. P.; FERREIRA, P.N.P.; CANÃS, J.J. Assessing operational impacts of automation using functional resonance analysis method. Cognition, Technology \& Work, v.21, p. 535-552, 2019.

PERRO, W. C. Normal Accidents: Living with High Risk Technologies - Updated Edition. Princeton, N.J.: Princeton University Press. 1999.

PORTELA, J. C. Abordagens de Segurança operacional da Usina Hidrelétrica Itaipu Binacional sob perspectiva da Engenharia de Resiliência. UFGRS, Porto Alegre, 2016. Disponível em <http://www.lume.ufrgs.br/handle/10183/156818>. Acesso em 29 ago. 2017.

PRAETORIUS, G.; HOLLNAGEL, E.; DAHLMAN, J. Modelling Vessel Traffic Service to understand resilience in everyday operations. Reliability Engineering and System Safety, v.141, p. 10-21, 2015.

RASMUSSEN, J. Risk management in a dynamic society: a modelling problem. Safety Science, v. 27, n.2, p. 183-213, 1997.

SHIRALI, G.A.; MOHAMMADFAM, I.; EBRAHIMIPOUR, V. A new method for quantitative assessment of resilience engineering by PCA and NT approach: A case study in a process industry. Reliability Engineering and System Safety, v. 119, p. 88-94, 2013. 
STEEN, R.; AVEN, T. A risk perspective suitable for resilience engineering. Safety Science, v.49, n. 2, p. 292-297, 2011.

SUJAN, M. A.; FELICI, M. Combining failure mode and functional resonance analyses in healthcare settings. Lect Notes Computer Science, v. 7612, p. 364-375, 2012.

VARGAS, C. V.; GUIMARÃES, L. B. M. A. Engenharia de Resiliência e o Sistema de Controle de Tráfego Aéreo. In: ENCONTRO NACIONAL DE ENGENHARIA DE PRODUÇÃO, 16, 2006. Anais...ABEPRO, Fortaleza - CE, 2006.

WACHS, P. Modelo para Integração entre melhorias de procedimentos operacionais padronizados e capacitação de operadores de Sistemas Sócios Técnicos Complexos. UFGRS, Porto Alegre, 2016. Disponível em: <http://www.lume.ufrgs.br/handle/10183/156475>. Acesso em 28 ago. 2017.

WOLTJER, R. Functional Modeling of Constraint Management in Aviation Safety and Command and Control. [s.l.] Linköpings Universitet, 2009.

WOODS, D. Essential Characteristics of Resilience. In: Hollnagel E, Woods D, Leveson N, editors. Resilience engineering: precepts and concepts. Abingdon: Ashgate Publishing Group; 2006. p. 21-34.

WZOREK, L.; REZENDE, D. A.; MENDES, J. M. G. Sistemas de Informação de apoio à decisão e suas relações com processos decisórios: Estudo de caso em um município paranaense. Revista eletrônica de Sistema de Informação, v.7, n.2, artigo 7, 2008.

YANG, J.; YUAN, M.; YIGITCANLAR, T.; NEWMAN, P.; SCHULTMANN, F. Managing knowledge to promote sustainability in Australian transport infrastructure projects. Sustainability, v. 7, n.7, p. 8132-8150, 2015. 